\title{
Analysis of the Impact of Graphs in School Certificate Biology Examination in Mpika District, Zambia
}

\author{
Samuel Boby ${ }^{1}$, Elizabeth B. Samuel ${ }^{2}$, Henry Mvula ${ }^{3}$, Erasmus Kwenge ${ }^{4}$ \\ ${ }^{1,2,3}$ School of Mathematics and Natural Sciences, Copperbelt University, P.O.Box 21692, Kitwe, Zambia \\ ${ }^{4}$ Mpika Boys Secondary School, P.O.Box 450142, Mpika, Zambia
}

\begin{abstract}
The study was aimed at determining the factors that make pupils fail to answer graph questions, estimate and interpret graphs in biology correctly. The study was conducted in four schools in Mpika District of Zambia. Three research questions were raised and answered by means of questionnaires that were administered to 142 pupils and 13 biology teachers. To determine the factors, the five points Likert rating scale was used. Data were analyzed using simple frequency counts, percentages and also the constant comparative method that involved a continual process of comparing pieces of data and identifying similarities and differences between them for generating patterns or categories from data. The results of the study showed that lack of content knowledge by biology teachers on graphs, educational materials such as graph papers and mathematical instruments were the key factors. Some strategies were adopted to enhance the teaching and learning of graphs in biology.
\end{abstract}

Keywords: graphs, mathematics, biology, connection, relationship

\section{Background of the Study}

The study of Biology connects us to the world we are living in and reminds us of our world interconnectedness with other living things. According to Alton B ,Chris K and Linda L (1998), Biology is the study of life. It provides opportunities to pupils to learn about the processes of living things. What pupils learn is directly relevant to living creatures and the environment. By learning Biology, pupils are able to make more informed decisions about their own health, use of antibiotics and significant biological issues such as HIV/AIDS and several other disorders and diseases. Biology helps pupils to recognize the importance of farming and how it potentially contributes to their future. Pupils become knowledgeable about ecological issues by learning Biology and they are able to debate on the exploitation of the environment. In other words pupils learn Biology in order to appreciate the great diversity of species on Earth and the way each species fits in to the dynamic pattern of life on Earth (Alton B, etal, 1998).

Although mathematics has long been intertwined with the biological sciences, an explosive synergy between biology and mathematics seems poised to enrich and extend both fields greatly in the coming decades (Levin,1992; Murray,1993;Jungck,1997;Hastings etal. 2003;Palmer etal.2003; Hastings and Palmer 2003). Mathematical biology aims at the mathematical representation and modeling of biological processes, using a variety of applied mathematical techniques and tools such as graphs. For example, in cell biology, interactions are often represented as cartoon models, which, although easy to visualize, do not accurately describe the systems studied. In order to do this, precise mathematical models are required. Hence, the need for the pupils to be knowledgeable on how to draw graphs and interpret the information from the graphs.

\section{Statement of the Problem}

In Zambia, the senior secondary school students fail to answer questions in biology involving mathematical concepts especially from graphs like how to draw, analyze, estimate and interpret. This contributes to the low passing rate at senior secondary level in biology examination. This failure is an indication that even though the graphs topics are taught in mathematics, students fail to apply this knowledge in biological situations. The chief examiner's annual reports in Biology in the School Certificate Examinations (SCE) conducted by the Examinations Council of Zambia (ECZ) of 2008 and 2013 are good testimonies of that, candidates do not perform well on questions involving graphs in biology.

\section{Research Objectives}

The following were the objectives of the study:

1) To assess the knowledge which pupils do not have on graphs in Biology.

2) To investigate the reasons for the students not answering the questions correctly on graphs in Biology.

3) To adopt strategies to enhance the teaching and learning of graphs in Biology.

\section{Research Questions}

The following research questions were generated:

1) What knowledge pupils do not have on graphs in Biology?

2) Why are pupils not able to answer questions correctly on graphs in Biology?

3) What strategies can be adopted to enhance the teaching and learning of graphs in Biology? 


\section{International Journal of Science and Research (IJSR) \\ ISSN (Online): 2319-7064 \\ Index Copernicus Value (2013): 6.14 | Impact Factor (2014): 5.611}

\section{Literature Review}

Biology as a subject cannot be studied in isolation of other subjects if it is to be understood and appreciated by the pupils. Biology has a special relationship with Mathematics because of its nature and that is why according to Ortiz (2006), connecting Biology and Mathematics requires prepared minds, to be successful. Adding a few mathematical subjects and these taught by mathematics experts to the university curriculum won't work, because students will not discover the connections by themselves. Even if someone were to show them the connections, they would probably stay within the safe field of Biology when discussing the biological issues (Ortiz, 2006). For this reason there is need to show the connection between mathematics and biology as early as elementary school mathematics and continue throughout all pre university or pre college education. This doesn't mean that biology teacher should teach mathematics or mathematics teacher should teach biology. Both subjects should be taught by experts, but some overlapping zone must be found on the attractive content level and pedagogy of teaching. Mathematical biology or biological mathematics content knowledge for all teachers should be established. One suitable model to be reworked is the model of pedagogical content knowledge (Shulman, 1987).

The most important part of the model to be considered is the connection between mathematics and biology in the pedagogical biological mathematical content knowledge (Kalin \&Zulijan2007). In reality, many biological processes can be described with the use of the above mentioned model using high school mathematics. To compile a curriculum based on content from both biology and mathematics will, by analogy, be the easiest part, but the transformation of outdated teaching may require more time and effort. So the safest way to be successful in connecting these disciplines is to start thinking about professional development of pedagogical mathematical biological content knowledge in the education of prospective elementary, biology and mathematics teachers.

Researchers and educators today are closely collaborating with mathematicians and scientists from other fields. Even if tomorrow's biologists had a more extensive mathematical and computational background, a single person could not, in general, pursue all these fields in depth; thus, the formation of interdisciplinary collaborations continues to be essential in the pursuit of biology (Karsai and Knisley 2009). We are now starting to understand that the amazing complexity and diversity of living organisms commonly stems from ultimately simple rules that can be explored by computational and mathematical means (Kauffman, 1993). Although Thompson's attitude is widely present in the scientific culture today, we maintain that mathematics alone will not turn a field into science, but the application of the scientific method do. To illustrate this, we intend to show how mathematics, inquiry-based learning, and the application of a modern philosophy of science could produce pedagogy to better teach biology as a science. We hope that new areas at the crossroads of biology and mathematics will soon develop to a level where biologists can use them intuitively and they can also be incorporated into education.
The eukaryotic cell is very complex and is one of the most studied topics, since its misregulation leads to cancers. It is possibly a good example of a mathematical model as it deals with simple calculus but gives valid results. Two research groups have produced several models of the cell cycle simulating several organisms. They have recently produced a generic eukaryotic cell cycle model which can represent a particular eukaryote depending on the values of the parameters, demonstrating that the idiosyncrasies of the individual cell cycles are due to different protein concentrations and affinities, while the underlying mechanisms are conserved (Csikász-Nagy, Attila; Battogtokh, Dorjsuren; Chen, Katherine C; Novák, Béla; Tyson, John J (2006)). The main goal of teaching both Mathematics and Biology is to help students develop capacity for critical thinking and problem solving (Gross 2004, Abell and Lederman, 2007)

\section{Methodology}

The population of this study consisted of 142 students and 13 biology teachers selected from four secondary schools in Mpika district, Zambia. Purposive random techniques were used to select these students and data were collected by a combination of qualitative and quantitative methods. At first an assessment test was given to find the understanding of the students in graphs in biology together with some biological questions from the same area. After analyzing the pupils' answers to the assessment test in graphs in biology a second questionnaire was given to the same group of students to find out the difficulties faced by them in answering graphical questions in biology and the possible causes. Questions were also included to check on the weaknesses the students had in some mathematical areas. A third questionnaire was distributed to 13 biology teachers. The data were analyzed using simple frequency counts, percentages and also the constant comparative method that involved a continual process of comparing pieces of data and identifying similarities and differences between them for generating patterns or categories from data.

\section{Results}

Research question 1. What knowledge pupils do not have on graphs in biology? An assessment test for graphs in biology was given to the students in order to find out what knowledge the students do not have in graphs in biology. Each question had some biology part also to check whether students have problems in answering biological part like graphical questions.

Table 1: Frequencies of students on the question involving the knowledge required to identify different parts of an eye.

\begin{tabular}{|c|c|c|c|c|c|c|c|c|c|}
\hline & \multicolumn{9}{|c|}{ Number of students who } \\
\hline & \multicolumn{6}{|c|}{ labeled $\mathrm{X}, \mathrm{Y}$ and $\mathrm{Z}$} & \multirow{2}{*}{\multicolumn{3}{|c|}{$\begin{array}{l}\text { described any two } \\
\text { changes in the ciliary } \\
\text { muscles and lenses }\end{array}$}} \\
\hline & \multicolumn{2}{|c|}{$\mathrm{X}($ retina $)$} & \multicolumn{2}{|c|}{ Y(lens) } & \multicolumn{2}{|c|}{$\mathrm{Z}$ (iris) } & & & \\
\hline & c & $\mathrm{w}$ & $\mathrm{c}$ & $\mathrm{w}$ & $\mathrm{c}$ & $\mathrm{W}$ & $1 \mathrm{c}$ & $2 \mathrm{c}$ & $2 \mathrm{w}$ \\
\hline Mpika boys & 28 & 4 & 30 & 2 & 30 & 2 & 16 & 4 & 12 \\
\hline Mpika day & 30 & 10 & 36 & 4 & 34 & 6 & 24 & 10 & 6 \\
\hline Chitiluka & 14 & 21 & 27 & 8 & 11 & 24 & 18 & 8 & 9 \\
\hline Mpika girls & 21 & 14 & 28 & 7 & 28 & 7 & 14 & 7 & 14 \\
\hline Total & 93 & 49 & 121 & 21 & 103 & 39 & 72 & 29 & 41 \\
\hline
\end{tabular}




\section{International Journal of Science and Research (IJSR) \\ ISSN (Online): 2319-7064 \\ Index Copernicus Value (2013): 6.14 | Impact Factor (2014): 5.611}

Key: $\mathrm{c}=$ correct, $\mathrm{w}=$ wrong

Table 2: Frequencies of the students on the questions which require the graphical applications like plotting the data, drawing the graph, estimating and interpreting from the graph, when the scales were not given

\begin{tabular}{|c|c|c|c|c|c|c|c|c|c|c|c|c|c|c|}
\hline \multirow{3}{*}{ School } & \multicolumn{14}{|c|}{ Number of students who } \\
\hline & \multicolumn{2}{|c|}{ Labeled axes } & \multicolumn{2}{|c|}{$\begin{array}{l}\text { Chose } \\
\text { scale }\end{array}$} & \multicolumn{2}{|c|}{$\begin{array}{c}\text { Plotted } \\
\text { minimum } 4 \\
\text { points }\end{array}$} & \multicolumn{2}{|c|}{$\begin{array}{l}\text { Joined the } \\
\text { points by a thin } \\
\text { and smooth } \\
\text { curve }\end{array}$} & \multicolumn{2}{|c|}{$\begin{array}{l}\text { Got the shortest } \\
\text { distance from } \\
\text { the eye for a } \\
\text { clear vision for a } \\
35 \text { year old } \\
\text { person }\end{array}$} & \multicolumn{2}{|c|}{$\begin{array}{l}\text { Got the age of a } \\
\text { person whose } \\
\text { shortest distance } \\
\text { from the eye } \\
\text { for a clear vision } \\
\text { of } 30 \mathrm{~cm}\end{array}$} & \multicolumn{2}{|c|}{$\begin{array}{l}\text { Described the } \\
\text { effect of getting } \\
\text { older on the } \\
\text { distance from } \\
\text { the eye for a } \\
\text { clear vision }\end{array}$} \\
\hline & $\mathrm{c}$ & $\mathrm{w}$ & $\mathrm{c}$ & $\mathrm{w}$ & $\mathrm{c}$ & $\mathrm{w}$ & $\mathrm{c}$ & $\mathrm{w}$ & $\mathrm{c}$ & $\mathrm{w}$ & $\mathrm{c}$ & $\mathrm{w}$ & $\mathrm{c}$ & $\mathrm{w}$ \\
\hline Chitiluka & 27 & 8 & 14 & 21 & 25 & 10 & 25 & 10 & 10 & 25 & 12 & 23 & 2 & 33 \\
\hline Mpika day & 20 & 20 & 12 & 28 & 18 & 22 & 16 & 24 & 12 & 28 & 10 & 30 & 8 & 10 \\
\hline Mpika boys & 16 & 16 & 10 & 22 & 16 & 16 & 14 & 18 & 16 & 16 & 12 & 20 & 0 & 32 \\
\hline Mpika girls & 7 & 8 & 7 & 28 & 7 & 28 & 7 & 28 & 7 & 28 & 7 & 28 & 0 & 35 \\
\hline Total & 70 & 72 & 43 & 99 & 66 & 76 & 62 & 80 & 45 & 97 & 41 & 101 & 10 & 132 \\
\hline
\end{tabular}

Key: $\mathrm{c}=$ correct, $\mathrm{w}=$ wrong

Table 3: Frequencies of the students on the question which requires the knowledge to draw and describe graphs when scales were already given

\begin{tabular}{|c|c|c|c|c|c|c|c|c|c|c|c|c|c|c|c|c|}
\hline \multirow[t]{4}{*}{ School } & \multicolumn{16}{|c|}{ Number of students who } \\
\hline & \multirow{2}{*}{\multicolumn{2}{|c|}{\begin{tabular}{|c}
$\begin{array}{c}\text { Plotted minimum } 5 \\
\text { points for graph }\end{array}$ \\
A
\end{tabular}}} & \multirow{2}{*}{\multicolumn{2}{|c|}{\begin{tabular}{|c|}
$\begin{array}{c}\text { Joined and } \\
\text { labeled as graph }\end{array}$ \\
B
\end{tabular}}} & \multicolumn{12}{|c|}{ Described for enzymes A and B } \\
\hline & & & & & \multicolumn{2}{|c|}{ A } & \multicolumn{2}{|c|}{ B } & \multicolumn{2}{|c|}{$\begin{array}{l}\text { Relative activity } \\
\text { increases }\end{array}$} & \multicolumn{2}{|c|}{ Best $\mathrm{pH}$} & \multicolumn{2}{|c|}{$\begin{array}{c}\text { Relative activity } \\
\text { decreases }\end{array}$} & \multicolumn{2}{|c|}{$\begin{array}{c}\text { No } \\
\text { reaction }\end{array}$} \\
\hline & $\mathrm{c}$ & $\mathrm{w}$ & $\mathrm{c}$ & $\mathrm{W}$ & $\mathrm{c}$ & $\mathrm{w}$ & $\mathrm{c}$ & $\mathrm{w}$ & $\mathrm{c}$ & $\mathrm{w}$ & $\mathrm{c}$ & $\mathrm{w}$ & $\mathrm{c}$ & $\mathrm{W}$ & $\mathrm{c}$ & $\mathrm{w}$ \\
\hline Chitiluka & 8 & 27 & 9 & 26 & 6 & 29 & 7 & 28 & 0 & 35 & 0 & 35 & 0 & 35 & 0 & 35 \\
\hline Mpika day & 18 & 22 & 12 & 28 & 16 & 24 & 18 & 22 & 4 & 36 & 6 & 34 & 2 & 38 & 0 & 40 \\
\hline Mpika boys & 4 & 28 & 2 & 30 & 2 & 30 & 2 & 30 & 0 & 32 & 0 & 32 & 0 & 32 & 0 & 32 \\
\hline Mpika girls & 7 & 28 & 14 & 21 & 7 & 28 & 14 & 21 & 0 & 35 & 0 & 35 & 0 & 35 & 0 & 35 \\
\hline Total & 37 & 105 & 37 & 105 & 31 & 111 & 41 & 101 & 4 & 138 & 6 & 136 & 2 & 140 & 0 & 142 \\
\hline
\end{tabular}

Table 4: Frequencies of the students on the question which requires the knowledge to draw a bar chart and some applications in biology

\begin{tabular}{|c|c|c|c|c|c|c|c|c|c|c|c|c|}
\hline \multirow[t]{3}{*}{ School } & \multicolumn{12}{|c|}{ Number of students who } \\
\hline & \multicolumn{2}{|c|}{ labeled the axes } & \multicolumn{2}{|c|}{$\begin{array}{c}\text { shaded and } \\
\text { written the key }\end{array}$} & \multicolumn{2}{|c|}{$\begin{array}{l}\text { got the height } \\
\text { of the bar }\end{array}$} & \multicolumn{2}{|c|}{$\begin{array}{l}\text { drew bars with } \\
\text { equal width and } \\
\text { gap }\end{array}$} & \multicolumn{2}{|c|}{$\begin{array}{l}\text { wrote the } \\
\text { meaning of } \\
\text { balanced diet }\end{array}$} & \multicolumn{2}{|c|}{$\begin{array}{l}\text { explained why an adult manual } \\
\text { worker needs more energy than } \\
\text { an adult office worker }\end{array}$} \\
\hline & $\mathrm{c}$ & $\mathrm{w}$ & c & W & $\mathrm{c}$ & $\mathrm{w}$ & $\mathrm{c}$ & $\mathrm{w}$ & $\mathrm{c}$ & w & $\mathrm{c}$ & W \\
\hline Chitiluka & 1 & 34 & 0 & 35 & 0 & 35 & 1 & 34 & 25 & 10 & 20 & 15 \\
\hline Mpika day & 8 & 32 & 6 & 34 & 6 & 34 & 6 & 34 & 20 & 20 & 34 & 6 \\
\hline Mpika boys & 4 & 28 & 0 & 32 & 0 & 32 & 0 & 32 & 20 & 12 & 8 & 24 \\
\hline Mpika girls & 7 & 28 & 0 & 35 & 0 & 35 & 0 & 35 & 28 & 7 & 28 & 7 \\
\hline Total & 20 & 122 & 6 & 136 & 6 & 136 & 7 & 135 & 93 & 49 & 90 & 52 \\
\hline
\end{tabular}

Table 5: Frequencies of the students on the question which requires the knowledge to draw a pie chart and some biological knowledge

\begin{tabular}{|c|c|c|c|c|c|c|c|c|c|c|c|c|c|c|}
\hline \multirow[t]{4}{*}{ School } & \multicolumn{14}{|c|}{ Number of students who } \\
\hline & \multicolumn{4}{|c|}{$\begin{array}{l}\text { suggested the most likely } \\
\text { method of }\end{array}$} & \multirow{2}{*}{\multicolumn{2}{|c|}{$\begin{array}{l}\text { explained any two } \\
\text { advantages of fruit } \\
\text { and seed dispersal } \\
\text { in flowering plants }\end{array}$}} & \multirow{2}{*}{\multicolumn{2}{|c|}{$\begin{array}{c}\text { got angle } \\
\text { proportions }\end{array}$}} & \multirow{2}{*}{\multicolumn{2}{|c|}{$\begin{array}{c}\text { drew pie } \\
\text { chart }\end{array}$}} & \multirow{2}{*}{\multicolumn{2}{|c|}{\begin{tabular}{|c|} 
got the $\%$ of \\
fruits that has the \\
weight of $161 \mathrm{~g}$
\end{tabular}}} & \multirow{2}{*}{\multicolumn{2}{|c|}{$\begin{array}{l}\text { got the relationship } \\
\text { between the length and } \\
\text { average weight of the } \\
\text { fruit }\end{array}$}} \\
\hline & \multicolumn{2}{|c|}{ seed dispersal } & \multicolumn{2}{|c|}{ pollination } & & & & & & & & & & \\
\hline & $\mathrm{c}$ & $\mathrm{w}$ & $\mathrm{c}$ & $\mathrm{w}$ & $\mathrm{c}$ & $\mathrm{w}$ & $\mathrm{c}$ & $\mathrm{w}$ & $\mathrm{c}$ & $\mathrm{w}$ & $\mathrm{c}$ & $\mathrm{w}$ & $\mathrm{c}$ & $\mathrm{W}$ \\
\hline Chitiluka & 26 & 9 & 12 & 23 & 14 & 21 & 0 & 35 & 0 & 35 & 1 & 34 & 0 & 35 \\
\hline Mpika day & 32 & 8 & 2 & 38 & 12 & 28 & 0 & 40 & 0 & 40 & 0 & 40 & 0 & 40 \\
\hline Mpika boys & 20 & 12 & 4 & 28 & 4 & 28 & 0 & 32 & 0 & 32 & 0 & 32 & 0 & 32 \\
\hline Mpika girls & 35 & 0 & 14 & 21 & 28 & 7 & 0 & 35 & 0 & 35 & 0 & 35 & 0 & 35 \\
\hline Total & 113 & 29 & 32 & 110 & 58 & 84 & 0 & 142 & 0 & 142 & 1 & 141 & 0 & 142 \\
\hline
\end{tabular}




\section{International Journal of Science and Research (IJSR) \\ ISSN (Online): 2319-7064 \\ Index Copernicus Value (2013): 6.14 | Impact Factor (2014): 5.611}

Table 6: Students responses on what knowledge they have on graphs in biology

Statements

1. If given the information and scale already on both axes ,I am able to plot the data

\begin{tabular}{|l|l|l|l|l|}
\hline SA & A & NS & DA & SD \\
\hline 40 & 66 & 12 & 20 & 4 \\
\hline 18 & 42 & 46 & 22 & 14 \\
\hline 36 & 58 & 14 & 24 & 10 \\
\hline 64 & 64 & 2 & 12 & 0 \\
\hline 40 & 44 & 12 & 36 & 10 \\
\hline 62 & 38 & 2 & 30 & 10 \\
\hline 40 & 60 & 10 & 22 & 10 \\
& & & & \\
\hline 30 & 54 & 10 & 36 & 12 \\
\hline 36 & 50 & 14 & 28 & 14 \\
\hline
\end{tabular}

2.If given the information only, I can determine a suitable scale to draw the graph

3.lf both axes are not labeled, the graph has no meaning

4.If the points are plotted ,I have no problems to join the points and draw the curve

5.I always find it difficult to estimate from the graph

6.I always find it difficult to interpret the results from the graph

7.I cannot illustrate the biological information correctly using bar chart, because I don't know how to

draw a bar chart

8.I cannot illustrate the information given in a pie chart because ,I do not know how to draw a pie chart

9. When we are learning graphs in mathematics our mathematics teacher doesn't show how the

knowledge of graphs can be applied to other subject like Biology

Key: $\mathrm{SA}=$ Strongly Agree, $\mathrm{A}=$ Agree, $\mathrm{NS}=$ Not Sure, $\mathrm{DA}=$ Disagree, $\mathrm{SD}=$ Strongly Disagree

The responses from the students shown in table 6 for statements 1 to 8 had agreed with their performance in the assessment test.

Research question 2: Why are pupils not able to answer questions correctly on graphs in biology?

To answer this question, those students who had agreed that they have difficulties to answer questions correctly on graphs in biology were asked to choose different reasons from the questionnaire. The results are given in table 7.

Table 7: Responses of the students who agreed that they are not able to answer questions correctly on graphs in Biology

\begin{tabular}{|c|c|c|c|}
\hline Statement & Reasons & True & False \\
\hline \multirow{5}{*}{$\begin{array}{l}\text { If given the information and } \\
\text { scale already on both axes, I am } \\
\text { not able to plot the data because }\end{array}$} & 1did not learn in Mathematics & 4 & 32 \\
\hline & I was never taught by biology teacher & 22 & 14 \\
\hline & of my poor foundation ,I haven't understood & 20 & 16 \\
\hline & $\begin{array}{l}\text { of fear of graphs I still have problems in getting it correct, even though I have } \\
\text { understood }\end{array}$ & 34 & 2 \\
\hline & I don't like graph questions & 6 & 30 \\
\hline \multirow{5}{*}{$\begin{array}{l}\text { If given the information only ,I } \\
\text { cannot determine a suitable } \\
\text { scale to draw the graph because }\end{array}$} & not taught in Mathematics & 6 & 76 \\
\hline & never taught by biology teacher & 52 & 30 \\
\hline & of my poor foundation, I haven't understood & 50 & 32 \\
\hline & of fear I still have problems in getting it correct, even though I have understood & 58 & 24 \\
\hline & $\begin{array}{l}\text { I thought it is correct to choose the numbers given in the information on both axes the } \\
\text { way it is without choosing a suitable scale }\end{array}$ & 31 & 51 \\
\hline \multirow{5}{*}{$\begin{array}{c}\text { I always find it difficult to } \\
\text { estimate from the graph because }\end{array}$} & I was not taught in Mathematics & 10 & 74 \\
\hline & of my poor foundation,I haven't understood & 58 & 26 \\
\hline & I get confused to choose the given value on the correct axis & 60 & 24 \\
\hline & $\begin{array}{l}\text { even after choosing the given value on the correct axis ,I do not know how to get the } \\
\text { corresponding value }\end{array}$ & 40 & 44 \\
\hline & $\begin{array}{l}\text { of no accuracy in reading the figure from the graph even after choosing the given value } \\
\text { on the correct axis }\end{array}$ & 40 & 44 \\
\hline \multirow{5}{*}{$\begin{array}{l}\text { I always find it difficult to } \\
\text { interpret the results from the } \\
\text { graph because }\end{array}$} & I was not taught & 35 & 51 \\
\hline & of my poor foundation ,I haven't understood & 46 & 40 \\
\hline & $\begin{array}{l}\text { I get confused with which part of the graph are increasing, decreasing optimum and } \\
\text { constant }\end{array}$ & 41 & 45 \\
\hline & I have got problems to connect biological ideas into mathematics & 73 & 13 \\
\hline & I have got mathematical ideas ,but I don't know how to write it & 39 & 47 \\
\hline \multirow{5}{*}{$\begin{array}{l}\text { I cannot illustrate } \\
\text { the biological information } \\
\text { correctly using bar chart } \\
\text { because }\end{array}$} & I did not learn in Mathematics & 64 & 36 \\
\hline & I did not learn in Biology & 68 & 32 \\
\hline & I did not know that bars should be of equal width and gap & 70 & 30 \\
\hline & I did not know that bars have to be shaded and the correct key has to & 65 & 35 \\
\hline & $\begin{array}{l}\text { I did not know that scales and correct height has to be chosen and axes have to be } \\
\text { labeled }\end{array}$ & 63 & 37 \\
\hline \multirow{5}{*}{$\begin{array}{c}\text { I cannot illustrate the } \\
\text { information given in biology in } \\
\text { a pie chart because }\end{array}$} & I did not learn in Mathematics & 24 & 60 \\
\hline & I did not learn in Biology & 61 & 23 \\
\hline & I did not know how to find angle proportion in a pie chart & 62 & 22 \\
\hline & I did not know how to measure the angles correctly and draw it in a pie chart & 48 & 36 \\
\hline & I did not know how to label and write the correct key & 51 & 33 \\
\hline \multirow{4}{*}{$\begin{array}{l}\text { Other possible causes which } \\
\text { the students felt that contribute } \\
\text { to the poor performance in } \\
\text { questions involving graphs in } \\
\text { biology }\end{array}$} & $\begin{array}{l}\text { Most parents do not support their children buying them like mathematical instrument } \\
\text { and graph papers }\end{array}$ & 72 & 70 \\
\hline & The school doesn't have enough mathematical instruments that can be used in class & 120 & 22 \\
\hline & I fear mathematical questions in Biology & 52 & 88 \\
\hline & I do not answer questions involving graphs because, it require more time to answer and & 58 & 84 \\
\hline
\end{tabular}

\section{Volume 4 Issue 11, November 2015}




\section{International Journal of Science and Research (IJSR) \\ ISSN (Online): 2319-7064}

Index Copernicus Value (2013): 6.14 | Impact Factor (2014): 5.611

\begin{tabular}{|l|c|c|}
\hline also I don't get it correct & & \\
\hline $\begin{array}{l}\text { I like Biology more than Mathematics hence ,I do not practice graphical questions in } \\
\text { Biology }\end{array}$ & 82 & 60 \\
\hline
\end{tabular}

Table 8: Teachers' questionnaire on the content knowledge on graphs in biology

The result of the study revealed that teachers were lacking content knowledge on graphs hence, being unable to teach the topic effectively. Lack of having sound knowledge in mathematics among biology teachers contributed to this situation resulting in poor performance by the pupils. The other contributing factor was inadequate teaching and learning materials regarding biology and teachers not having mathematical instruments that can facilitate the teaching of graphs

\begin{tabular}{|c|c|c|c|c|c|c|}
\hline $\mathrm{S} / \mathrm{n}$ & Statements & SA & A & NS & $\mathrm{D}$ & SD \\
\hline 1 & If I am given the information, I can determine a suitable scale to draw the graph. & $\begin{array}{c}1 \\
7.7 \% \\
\end{array}$ & $\begin{array}{c}5 \\
38.5 \% \\
\end{array}$ & $\begin{array}{c}7 \\
53.8 \%\end{array}$ & $\begin{array}{c}0 \\
0 \%\end{array}$ & $\begin{array}{c}0 \\
0 \%\end{array}$ \\
\hline 2 & $\begin{array}{l}\text { I always find it difficult to interpret the results on the graph when I am preparing and } \\
\text { teaching graph work in biology }\end{array}$ & $\begin{array}{c}0 \\
0 \%\end{array}$ & $\begin{array}{c}4 \\
30.8 \%\end{array}$ & $\begin{array}{c}0 \\
0 \%\end{array}$ & $\begin{array}{c}8 \\
61.5 \%\end{array}$ & $\begin{array}{c}1 \\
7.7 \%\end{array}$ \\
\hline 3 & When I was at secondary school, in biology I was not taught how to draw graphs. & $\begin{array}{c}2 \\
15.4 \% \\
\end{array}$ & $\begin{array}{c}7 \\
53.8 \% \\
\end{array}$ & $\begin{array}{c}0 \\
0 \% \\
\end{array}$ & $\begin{array}{c}4 \\
30.8 \% \\
\end{array}$ & $\begin{array}{c}0 \\
0 \% \\
\end{array}$ \\
\hline 4 & $\begin{array}{l}\text { When we were learning graphs in mathematics at secondary school, our mathematics } \\
\text { teacher did not show how the knowledge of graphs can be applied to other subjects like } \\
\text { biology. }\end{array}$ & $\begin{array}{c}4 \\
30.8 \%\end{array}$ & $\begin{array}{c}2 \\
15.4 \%\end{array}$ & $\begin{array}{c}1 \\
7.7 \%\end{array}$ & $\begin{array}{c}4 \\
30.8 \%\end{array}$ & $\begin{array}{c}2 \\
15.4 \%\end{array}$ \\
\hline 5 & $\begin{array}{l}\text { I do not have personal mathematical instruments which I can use for drawing graphs in } \\
\text { biology. }\end{array}$ & $\begin{array}{c}4 \\
30.8 \%\end{array}$ & $\begin{array}{c}7 \\
53.8 \%\end{array}$ & $\begin{array}{c}0 \\
0 \%\end{array}$ & $\begin{array}{c}1 \\
7.7 \%\end{array}$ & $\begin{array}{c}1 \\
7.7 \%\end{array}$ \\
\hline 6 & $\begin{array}{l}\text { The school does not have enough mathematical instruments that can be used in drawing } \\
\text { graphs in biology. }\end{array}$ & $\begin{array}{c}6 \\
46.1 \% \\
\end{array}$ & $\begin{array}{c}5 \\
38.5 \% \\
\end{array}$ & $\begin{array}{c}2 \\
15.4 \%\end{array}$ & $\begin{array}{c}0 \\
0 \% \\
0\end{array}$ & $\begin{array}{c}0 \\
0 \%\end{array}$ \\
\hline 7 & The school does not provide the graph papers when we are teaching graphs in biology. & \begin{tabular}{c|c|}
1 \\
$7.7 \%$
\end{tabular} & $\begin{array}{c}9 \\
69.2 \% \\
\end{array}$ & $\begin{array}{c}2 \\
15.4 \%\end{array}$ & $\begin{array}{c}1 \\
7.7 \%\end{array}$ & $\begin{array}{c}0 \\
0 \%\end{array}$ \\
\hline 8 & $\begin{array}{l}\text { In my learning period, I was not managing to answer questions involving graphs because I } \\
\text { was unable to get them correct. }\end{array}$ & $\begin{array}{c}1 \\
7.7 \%\end{array}$ & $\begin{array}{c}6 \\
46.1 \%\end{array}$ & $\begin{array}{c}1 \\
7.7 \%\end{array}$ & $\begin{array}{c}3 \\
23.1 \%\end{array}$ & $\begin{array}{c}2 \\
15.4 \%\end{array}$ \\
\hline 9 & $\begin{array}{l}\text { I cannot illustrate the information given in biology using pie chart and histogram because I } \\
\text { do not know how to draw the pie chart and histogram. }\end{array}$ & \begin{tabular}{|c|}
1 \\
$7.7 \%$ \\
\end{tabular} & $\begin{array}{c}6 \\
46.1 \% \\
\end{array}$ & $\begin{array}{c}1 \\
7.7 \% \\
\end{array}$ & $\begin{array}{c}3 \\
23.1 \% \\
\end{array}$ & $\begin{array}{c}2 \\
15.4 \% \\
\end{array}$ \\
\hline 10 & $\begin{array}{l}\text { At the college/university, we did not do a lot of graph work involving mathematics in } \\
\text { biology, hence I lack strong mathematical background as a teacher. }\end{array}$ & $\begin{array}{c}0 \\
0 \% \\
\end{array}$ & $\begin{array}{c}8 \\
61.5 \% \\
\end{array}$ & $\begin{array}{c}0 \\
0 \% \\
\end{array}$ & $\begin{array}{c}3 \\
23.1 \% \\
\end{array}$ & $\begin{array}{c}2 \\
15.4 \% \\
\end{array}$ \\
\hline
\end{tabular}

Research question 3: What strategies can be adopted to enhance the teaching and learning of graphs in biology? A questionnaire was given to 13 teachers of Biology on the strategies to be adopted to enhance the teaching and learning of graphs in Biology. The results are summarized in table 9.

Table 9: Strategies to enhance the teaching and learning of graphs in biology

\begin{tabular}{|c|c|c|c|c|c|c|c|}
\hline $\mathrm{s} / \mathrm{n}$ & Statements & $\overleftrightarrow{\sim}$ & $\varangle$ & 乙 & a & 命 & $\begin{array}{l}\text { ॠ } \\
\sum_{\Sigma}^{\infty} \\
\end{array}$ \\
\hline 1 & Biology topics involving graph work should be included in mathematics syllabus & 2 & 4 & 1 & 6 & 0 & 3.15 \\
\hline 2 & Teachers of mathematics should teach biology topics involving graphs & 0 & 2 & 1 & 8 & 2 & 2.23 \\
\hline 3 & Schools should buy enough educational materials needed for teaching graphs in biology & 7 & 2 & 2 & 1 & 0 & 3.92 \\
\hline 4 & $\begin{array}{c}\text { Science and mathematics Department should be discussing areas of common coverage especially in } \\
\text { biology together }\end{array}$ & 9 & 0 & 1 & 3 & 0 & 4.15 \\
\hline 5 & $\begin{array}{l}\text { Teachers of biology and mathematics should be able to show how mathematics and biology are } \\
\text { inter-connected }\end{array}$ & 9 & 1 & 3 & 0 & 0 & 4.46 \\
\hline 6 & Teachers of biology need to show biology pupils that mathematics skills are essential in biology & 9 & 3 & 1 & 0 & 0 & 4.61 \\
\hline 7 & $\begin{array}{c}\text { Teachers of mathematics should make pupils understand that what they learn in mathematics can be } \\
\text { applied in biology especially graphs }\end{array}$ & 9 & 2 & 1 & 0 & 0 & 4.31 \\
\hline
\end{tabular}

The responses from the teachers were computed using the five point Likert scale to determine the strategies that should be adopted to enhance the teaching and learning of graphs in biology. The mean value for acceptance was $x \geq 3$ otherwise rejected.

\begin{tabular}{|c|c|c|c|c|c|c|}
\hline Response & $\begin{array}{c}\text { Strongly } \\
\text { Agree }\end{array}$ & Agree & $\begin{array}{c}\text { Not } \\
\text { Sure }\end{array}$ & Disagree & $\begin{array}{c}\text { Strongly } \\
\text { Disagree }\end{array}$ & Total \\
\hline Score & 5 & 4 & 3 & 2 & 1 & 5 \\
\hline
\end{tabular}

Mean score $=\frac{15}{5}=3$
The mean response on table 9 shows that the teachers accepted 6 of out of 7 factors with mean score of more than 3 as the strategies that could enhance the teaching and learning of graphs in biology if adopted. The mean values accepted ranges from 3.15 to 4.61 which are in line with the criteria.

\section{Discussion and findings}

The purpose of the study was to identify the factors that are affecting the pupils, why they were not able to answer the questions correctly on graphs in Biology by using responses from teachers and students. An assessment test which

\section{Volume 4 Issue 11, November 2015}




\section{International Journal of Science and Research (IJSR) \\ ISSN (Online): 2319-7064 \\ Index Copernicus Value (2013): 6.14 | Impact Factor (2014): 5.611}

contained biological knowledge and graphical questions in Biology were given to the students, which revealed that the students were more capable to answer pure biology questions compared to the questions involving the application of biological knowledge and graphical questions in Biology. This is because most biology teachers were lacking content knowledge on graphs in biology and hence they don't show the students how to answer the questions in graphs. To teach all learners according to today's standards, teachers need to understand subject matter deeply and flexibly so that they can help the learners to create useful cognitive diagrams, relate one idea to another, and address misconceptions. Teachers need to see how ideas connect across fields and to everyday life. This kind of understanding provides a foundation for pedagogical content knowledge that enables teachers to make ideas accessible to others (Shulman, 1987). This shows that Ministry of Education must ensure that the biology teachers must be given some sort of in-service training in this area. As a result of lack of content knowledge, teachers have not been teaching the graphical areas because, for the teacher to teach effectively he/she needs content knowledge. This implies that the training institutions must ensure that teachers are trained in the key components of effective mathematics instruction which are: Subject-matter knowledge in mathematics (or the teacher's knowledge of the content being taught), mathematics topics for student mastery and knowledge about how to teach effectively mathematics (or the teacher's knowledge and use of effective instructional strategies in teaching mathematics). Preparing teacher candidates in these core competencies can result in more effective instructional processes and outcomes and the advancement of student learning in mathematics (National Mathematics Advisory Panel, 2008). Another problem is when the mathematics teacher teaches graphs, he/she never connects the graphical knowledge into biological situations.

The study revealed that students had more problems to plot the points when the scales were already given compared to coming up with their own scales. They are better off to come up with their own scale and plot the points. Most of them while choosing the scale were making unequal intervals on either of the axes; inserting table values as it is in the table irrespective of the intervals and also if the table values start with a number other than zero for either both or one of the axes, they were not able to choose the correct start. Some students even plotted the points accurately according to the wrong scale chosen while, some others got wrong because, they failed to follow the scale. The students had not much problems to join the points by a smooth curve but some used too thick and the curve had some discontinuities. Students did not do well in the estimation which requires locating a given value along the correct axes and drawing a vertical (horizontal) line until it reaches the curve then, drawing a horizontal line (vertical) until it cuts the other axis. Also some failed to read the point accurately. Most of the students failed to connect the biological ideas and the interpretation of the graph as increasing, decreasing, maximum and stationary; they failed to describe the connection between the two variables or they failed to connect mathematical concepts into biological situations. Some of them had problems to plot two graphs on the same axes.
Most of the students had problems to label axes in the bar chart compared to the one in drawing a curve, and some even forgot to write the units. They had problems to draw bars with correct height because, the scale chosen along the vertical axis was wrong due to unequal interval selected. Most of them drew bars with unequal width and gap and did not write the key. Some of them even used the two variable values to plot it as points and joined the points by a curve which shows that they do not know the difference between a curve and a bar chart

No one drew the pie chart correctly because, they did not know how to calculate the angle proportion correctly and they never measured the angle correctly by a protractor.

A questionnaire was given to the students to get information about what are their strength and weakness in graphical questions and what are the reasons for that. The reasons given by the students were; even if they learnt in Mathematics, their poor foundation made them fail to understand and in addition to that most biology teacher never practiced any graphical biological questions in class. Most students do not have mathematical instrument and graph paper which is required to practice these types of questions. The school doesn't have enough educational materials to use in the class and also most parents do not support their children buying mathematical instrument and graph papers. Lack of practice, fear of Mathematics, lack of basic knowledge from lower grade like how to write biological ideas into mathematics, how to come up with their own scales and how to calculate angle proportion to draw pie chart all these created problems.

\section{Strategies to Enhance Teaching}

Teachers are the most important factor in schools (Kalin \& Zuljan, 2007); introduction of any new trend should start with them. To compile a curriculum based on content from both biology and mathematics will, by analogy, be the easiest part, but the transformation of outdated teaching may require more time and effort. So the safest way to be successful in connecting these disciplines is to start thinking about professional development of pedagogical mathematical-biological content knowledge in the education of prospective elementary, biology, and mathematics teachers.

For teaching and learning to be enjoyable and effective, learning materials should be available. Learning is strengthened when there are enough reference materials such as textbooks, exercise books, teaching aids and enough class rooms (Mutai, 2006). In the absence of enough educational materials, it is impossible to have interactive teaching because pupils if they have to participate fully and actively they need to have background information and they can only have this information if educational materials are available. The implication of this result is that provision of conducive classrooms, laboratories and other teaching/learning resources can positively change both teachers and pupils to have positive attitude towards mathematics (Mutai, 2006). If teachers' knowledge is to be enhanced, it needs the material, systems, human and emotional support provided by professional development initiatives. Support and resourcing

\section{Volume 4 Issue 11, November 2015}




\section{International Journal of Science and Research (IJSR) \\ ISSN (Online): 2319-7064 \\ Index Copernicus Value (2013): 6.14 | Impact Factor (2014): 5.611}

can also come from the joint efforts of other biology teachers within the school (Kazemi, 2008). Teachers of biology and mathematics should be able to show how mathematics and biology are inter-connected. The science and mathematics departments should be discussing areas of common interest especially in biology together.

\section{Conclusion}

Mathematics is regarded to be a tool for other subjects like biology. It is for this reason that the teachers of biology should have sound background in mathematics for them to teach graphs effectively, they need mathematical background on graphs. The teachers of biology and mathematics should be discussing areas of common interest so that they can acquire the skills which they need in order to draw graphs with less difficulties. School authorities should ensure that the necessary teaching and learning materials are available in school especially those needed in drawing graphs.

\section{Recommendations}

Based on the findings of the study, the following recommendations are made.

a) The biology teachers must be given some in-service training in graphs involving biology to improve their content knowledge.

b) Mathematics teachers should include biological graphs in their examples while they teach the topic on graphs in mathematics and biology teachers should revise the graphs in biology. Teachers of mathematics and biology should be able to discuss areas of common coverage.

c) The Heads of Mathematics Departments should ensure that graphical boards are available in the class rooms for the teachers to use for graphical questions.

d) Students should be given strong foundation in Mathematics in lower grades to boost their confidence and interest in Mathematics which includes graphs.

\section{References}

[1] Abell SK \& Lederman NG. (2007). Handbook of Research on Science Education. Lawrence Erlbaum Associates.

[2] Brent R. ( 2004). Intuition and innumeracy. Cell Biology Education 3: 88-90.

[3] Csikász-Nagy, Attila; Battogtokh, Dorjsuren; Chen, Katherine C.; Novák, Béla; Tyson, John J (2006)."Analysis of a generic model of eukaryotic cellcycle regulation".Biophys J.90(12):43614379.doi:10.1529/biophysj.106.081240. PMC 1471857.PMID 16581849.

[4] Gross LJ. 2004. Interdisciplinary and the undergraduate biology curriculum: Finding a balance. Cell Biology Education 3: 85-87.

[5] Hastings A, Palmer MA (2003) A bright future for biologists and mathematicians? Science 299: $2003-$ 2004.

[6] Jungck JR. (1997). Ten equations that changed biology: Mathematics in problem-solving biology curricula. Bioscience 23: 11-36
[7] KalinJ and Zuljan M.V, (2007).Teacher perceptions of the goals of effective school reform and their own role in it. Educ. Stud. 33:163-175.

[8] Kauffman S. (1993). The Origins of Order: Selforganization and Selection in Evolution. Oxford University Press.

[9] Karsai I,\&Knisley J.( 2009). The role of institutes in interdisciplinary research and education: An example from quantitative biology. Journal of College Science Teaching 38: 32-37.

[10] Kazemi, E. (2008). School development as a means of improving $\mathrm{g}$ mathematics teaching and learning. In $\mathrm{K}$. Krainer\& T. Wood (Eds.), Participants in mathematics teacher education (pp. 209-230). Rotterdam Netherlands: Sense.

[11]Levin S, (1992) Mathematics and biology: The interface. Challenges and opportunities. Lawrence Berkeley Laboratory Pub-701. Berkeley (California): University of California.

[12] Murray JA (1993) Mathematical biology, 2nd ed. Berlin: Springer-Verlag.

[13] Mutai, B.K.(2006). How to write quality research proposal: a complete and

[14] Simplified Recipe. New York: Talley Publications.

[15] National Mathematics Advisory Panel. (2008). Foundations for success: The final report of the National Mathematics Advisory Panel. Washington, DC: U.S. Department of Education. Retrieved December $\quad 16, \quad 2010, \quad$ from http://www2.ed.gov/about/bdscomm/list/mathpanel/rep ort/final-report.pdf

[16] Ortiz M. T. (2006). Numbers, neurons \& tides, oh my! Mathematics, the forgotten tool in biology. Am. Biol. Teach. 2006; 68:458-462.

[17] Shulman,L. (1987). Knowledge and Teaching. Harvard Educational Review, 57(1),1 - 22.

[18] Špernjak A and Šorgo A, (2009). Perspectives on the introduction of computer-supported real laboratory exercises into biology teaching in secondary schools: teachers as part of the problem. In: Lamanauskas V., editor. Challenges of Science, Mathematics, and Technology Teacher Education in Slovenia (Problems of Education in the 21st Century, vol. 14) Siauliai: Scientific Methodological Center Scientia Educologica; $135-143$. 